\title{
吾が教室に於ける骨腫痬について
}

\begin{tabular}{|c|c|c|c|c|}
\hline $\begin{array}{c}\text { 鳥取大学突学部慗形外科教室 } \\
\text { (主任; 西 教 授) }\end{array}$ & 花 & 北 & & 良 \\
\hline & 真 & 壁 & & 武 \\
\hline & 戸 & 口 & 田 & 和 \\
\hline $\begin{array}{l}\text { 鳥取大学医学部放射線科教空 } \\
\text { (主任 ; 阿 武 教 授) }\end{array}$ & 秋 & & & \\
\hline
\end{tabular}

\section{Studies of Bone Tumors in Our Clinic}

by

\author{
Y. Hanakita, T. Makabe \& K. Toguchida \\ Department of Orthopedic Surgery, Faculty of Medicine, Tottori University \\ (Direct.: Prof. A. Nishio)

\section{Y. Akiyama} \\ Department of Rodiology, Faculty of Medicine, Tottori University \\ (Direct. : Prof. Y. Amu.)
}

最近骨腫場に関する研究は整形外科学会でも盛に取 上げられ，就中九大に於ては骨腫堭の登録制を実施, 広汎な各種検査を行つて鋭意其の研究を進めて居られ るのであつて, 其の御努力に深い敬意を表するるので ある。然し去る 4 月の総会に於ても討論された如く, 骨睡煌に関しては先つ其の分類の点から異論が多く未 だ統一せる見解に達せず，更に診断，治療等に関して す佮未解决な分野が多く残されて居り, 而も比較的症 例が乏しい為に, 単に一教空一病院だけの研究では充 分の効果を期待し得ない現状である。以上の観点から. 骨腫場を広く蒐集し, 豊富な症例によつて着々研究を 遂行されつ小ある九大の御意眓に賛意を表し，乏しい 症例ながら我が教窒に於ける最近の骨腫湟研究の現状 と 2 3 の興味ある症例を追加し, 之が骨睡場登録制 にとつて御参考ともなれば幸と存じ, 敢て報告する次 第である。

昭和 29 年 1 月以降, 現在に至る約 2 ケ年半に当教 室を訪れた骨腫㿣患者は 31 例であつて，之を便宜上 Geschickter Copeland に従つて分類すれば第 1 表の 如くである。

$$
\text { 表 } 1 \text { 昭和 } 29 \text { 年 } 1 \text { 月以降の骨腫痬 }
$$

良性骨腫瘍惡性骨腫痬

骨軟骨腫及內軟骨腫 6 骨商嗹 6 良性巨暃細胞腫 4 惡性腫瘍骨轉移 11 骨震 腪 1 Fibrous dysplasia 1 V. Recklinghausen 氏病 1
1) 骨㳄骨腫及び内軟骨腫は 6 例であつて, 其の中 多発性のものは肩甲骨に巨大な睡瘤を形成した多発性 外骨腫と, 両側示指の掌骨及び指骨に発生した内軟骨 睡の 2 例で後者に対してのみ撜爬後自家骨移植を行つ たが，前者の如きものに対しても，形態上の醜形と二 次性軟骨肉腫 Secondary Chondrosarcoma への悪性 変化を考えれば睡場の摘出が望ましく，又他の 4 例は 何れる単発性であるが, '部位の点で興味あるのは中指 末指節に発生した 1 例である。

2）「レ」線上，骨吸収像を呈する所謂溶骨性良性 睡堭 (Resorptive type) として巨態細胞腫, 骨震腫, Fibrous dysplasia 等があるが, 之等は組織学的にも 相互間に移行型があり, 従来は所謂 Ostitis fibrosa localisata として記載されているものが多い。其の中, 巨態細胞腫は 4 例であるが, 其の発生部位は大臥骨下 端及び脛骨上端夫々 2 例宛で而も何れる Epiphyse に 発生して居り, 本骨睡愓の好発部位である。その中搔 爬骨移植を施したものは 3 例で】例は術后 10 ケ月 で，移植せる自家及び同種骨は母床と痛合し，空洞も 殆んど骨性に治翁し, 所期の目的を達した。然るに泉 例では 3 回に亘る撜爬, 骨移植にも拘はらず, 病変は其 の都度外方, 内方, 下方, 内後方へと進展し甚だ難治性 で, 組織所見も病理学的に所謂「巨態細胞肉腫」と診 断された程で, 間質細胞は円形又は棈円形で敏密に排 列し; 所々に出血, 核の軽度の Atypie る存し,

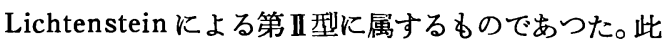
の事は本腫煌の手術に当つて出来る限り完全な撜爬が 
必要な事を意味すると共に, Lichtenstein, Geschickter 等子説く如く,本症の全例が所謂良性とは云い難 く, 中には潜在的に悪性のものがあつて再発, 悪性変 化更には枟移の可能性を有し，遂には切断の止むなき に至る症例の存する事実を裏書きするるので, 本例に は近々第 4 回目の手術施行の予定である。

上皮小体腺腫に基因する沉発性線维性骨炎の 1 例に ついては，既に昨年の本会で新宮が報告を行つたので （整形外科と災害外科， 5 巻， 1 号，56 頁）詳細は省 略するが, 腺腫摘出后 13 ケ月で骨折部は完全に癒合 し大眼骨部の震揰様狯影つみは偷残つているが，一般 に著しく硬化像を呈し，血液所見でもAlk-P-tase の 軽度上昇を残すのみで， $\mathrm{Ca}$ ，燐は全く正常である。

3) 骨肉腫の分類法には従来の単なる肉腫細胞の形 態学的分類によるすの（円形, 紡緟型, 巨態細胞肉腫 等)を始めとして，Geschickter and Copeland 或は American College of Surgeons 等の婳煌由来組織及 び其の発生段階による分類, 更には「レ」線所見による 分類等があつて一定していない。之に対し，Lichtenstein は骨肉畽の斯の如き細かい分類は却つて混乱の 恐れがあるとして，之以上の分類に重大な意義を認め て居らず，唯骨肉腫か否か，若し骨肉腫ならば其の予 后の良否, 血管分布の多頞,「レ」線上硬化性か：溶骨 性かの程度に分類するだけで充分と考兄ている。
1.

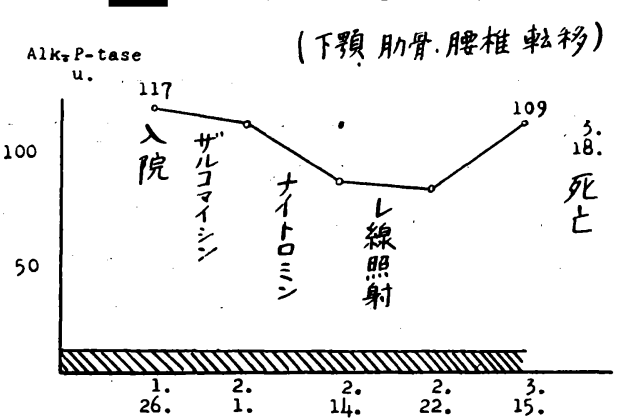

骨肉隀は 6 例で我々も Geschickter and Copeland に従い, 組湆学的に一応の分類は試みたけれども, 興 味ある事は 6 例中 5 例に於て。「レ」線上種 々な程度 に骨硬化像を示するのであつた事である。然し仔細に 観察すると「レ」線上大部分が硬化性でも一部に溶骨 性の部分があり, 切断漂本割面の肉眼的所見でも同棣 の所見が得られ，従つて大組職標本の製作は骨肉腫の 正確な診断上必須の要件であり, 我々も現在製作中で ある。以下此の 6 例につき「レ」線所見及び Alk-ptase 所見を中心に臨床经過を観察すると，

1. 長瀨例は組織学的に肉腫細胞が極めて幼若で, 核の染色性, 形態共に Atypie 甚しく,「レ」線像で
も著しい硬化像を示したが，其の Alk-P-tase 值は全 経過を通じ，100 単位前後という極めて高い值を示 し, 症状発見後 3 ケ月で早くも左下顎骨に転移，6 ケ 月后には死亡した。

2. 荒金例は症状発現后 1 ケ月で単純撮影で一応肺 転移なきを確め, 試験切除を行うことなく, 直ちに切 断を行つた症例で組職学的には造骨性肉腫に属するす のであつた。Alk-P-tase は切断後 3 週頃より漸次下 降したが，当初転移として認められなかつた肺部除影 が各種治潦にも拘はらず, 切断後 3 ケ月で断層撮影に より明かな転移として出現し, 而も其の增大, 両肺へ の広沉な進展によつて Alk-P-tase は濑次上算し, 遂 に切断後 16 ケ月で死亡した。剖見上, 肺には球状大 小様々の転移巣が累々と存し,「レ」線像でも同様に 硬化性, 円形の陰影として認められ, Alk-P-tase 増加 の所見を充分に裏付けるるのであつた。

2.

17 才 右大腿骨造骨性肉腫

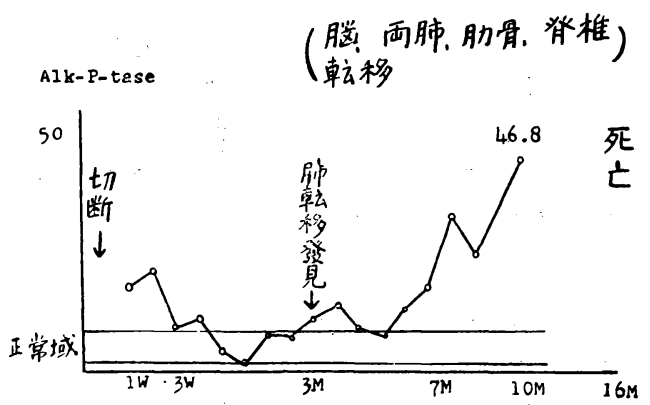

3. 田倉例も同様症状発現後 1 ケ月, 断層撮影で肺 転移なきを確め, 試験切除による事なく、「レ」線像, Alk-P-tase の中等度増加, 著明な貧血等の所見より, 骨肉腫と診断, 直ちに切断を行つた処，Alk-P-tase は 術后 1 週以后急激に下降し, 其の后略々正常值で推移 したが Alk-P-tase 正常なるにも拘はらず, 切断後 6 週 で断層撮影で右下葉に肺耘移を発見した。Alk-P-tase が切断により急激に下降した所見は其の血清中増加が 局所の造骨性病変に基因する事を改めて認識させるも のであるが，転移発生によつても Alk-P-tase が正常 なのは，其の消骎と転移との関係に時期的な，ずれの ある事を示している。又切断標本篧流后，血管造影の 所見では腫晹は血管分布豊富で, 此の事は肉腫の特性 として当然であるが，之に対する如何に小さな侵擎で 子睡漡細胞血行転移の危険性を多分に李んで居り，切 断術前の試験切除は極力避くべき事を暗示している。

4. 遠田例は症状発現后 2 ケ月目に来院し, その后 1 週目に都台により他の病院で切断を受けたが, 通信 調査の結果では其の後 1 ケ月で, 肺転移を来し, 切断 後 3 ケ月で死亡して居る。 
3.

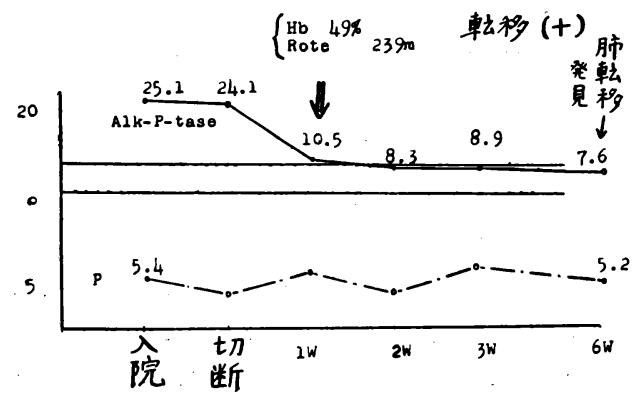

5. 加藤例の肺転移も切断后 4 ケ月半で断層撮影に より, 円形 2 ケの肺転移として発見され， 8 ケ月半后 には死亡している。

以上骨肉腫 6 例の観察によつて得られた知見から特 に強調したい事は第 1 に, 転移の可能性の為に, 試験 切除を行はずに現在最も有数と考えられる早期切断を 施行したにも拘はらず，その 3 例共切断後 1 〜 3 ケ月 という早期に，而も断層撮影により肺転移が発見され ている事実であつて, 果して切断を行わない場合でも, 斯くも早期に枟移を生ずるか否かの問題である。勿論 睡鈞の悪性度の影響もあり，対照も取り得ないので， 以上の所見だけから，早期切断の効果を何等否定する わのではないが，此の早期肺転移は，一見切断によつ て却つて促進されたとさへ感ぜられるのである。何れ にせよ, 肺坛移の診断は, 断層撮影によらなければ不 確実で, 更に切断による治療効果を少くとも Geschickter 等の 5 年治癒率，15〜25\%に引き上げる為には, 肉腫が局所に全く限局した早期に診断し，切断する事 が切に望まれるのであつて，治療成果の向上は一つに か〉つて此の早期診断法の如何にあるものと考える。

第 2 に転移発生時の Alk-P-tase の態度である。
Colley は其の著書で切断后 Alk-P-tase の正常復帰 は予后良好の徵としたにも拘はらず，荒金，田倉の 2 例共, 切断によつて Alk-P-tase は激減したが, 転移 発見時には正常であり，而も荒金例は肺転移が両肺に 拡大するに及んで始めて著増を示して居り，転移発生 は Alk-P-tase の増加に滛かに先行する事を知つたの である。従つて骨肉腫, 就中造骨機転旺盛なる場合は 明かに, Alk-P-tase の増加があるが,一般骨肉腫に関 する Colley の規準に対しては，更に症例を重ねて再 吟味すべき問題があると考える。

4 . 悪性腫瘍骨転移症例は 11 例である。一般に骨 癌転移は部位的に試験切除を行い難い事が多く, 其の 診断も従つて困難な場合がある。例は生存中, 頸 椎「カリエス」として治療され, 剖見により始めて Grawitz の腫瘍枟移と確定したもので, 脊椎を好発部 位とする癌転移と「カリエス」との鑑別診断が時とし て困難な事を示している。又興味あるのは，甲状腺癌 が大眼骨幹部に転移し，2 ケ所の棈円形透明巣を生じ, 其の 1 ケ所で病的骨折をおこした 1 例である。一般に 癌秐による病的骨折は, 仮骨形成不充分なるを常と するが，本例では Alk-P-tase は正常ながら，1 1 月 后比較的多量の仮骨形成をみている。例は左側钼 部の睡湯形成を主訴として来院し, 入院后発見された 第 4 胸椎の扁平化が, Calvè 氏屚平椎様に短期間に著 しく進展し，遂に死の転帰を取つたもので，死後剖見 により,「リンパ」肉腫の骨転移と診断され, 他の各処 にも法移がみられた症例である。Alk-P-tase の測定 は 5 例に過ぎないが，昨年の総会に於て報告した如 く, 前立腺癌転移を除く, 溶骨性癌転移では Alk-Ptase の増加はないるのと確信する。

表 2

骨肉腫に於ける切断と予后

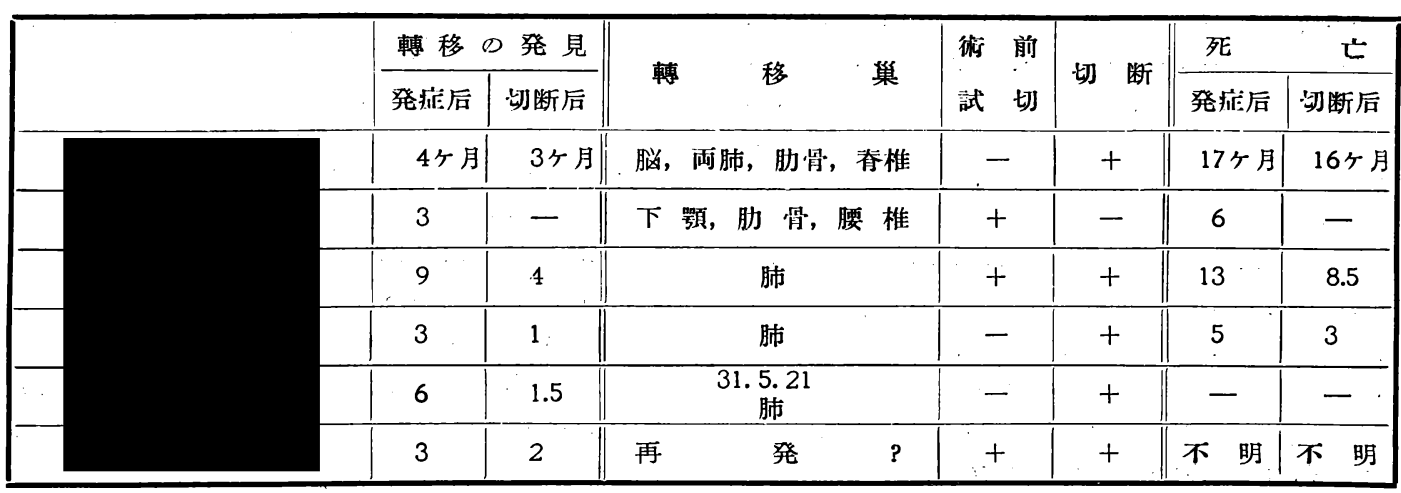




\section{結}

熺

1. 昭和 29 年以降, 当教室に於ける骨腫踼は 31 例 に達し, 其の内訳は良性骨睡愓 14 例, 骨肉畽 6 例, 癌轱移 11 例である。

2. 巨態細胞腫の 1 例は 3 回の掻爬，骨移植術にも 拘はらず根治に至らず，近々 4 回の手術施行予定の 1 例であり，本应の全例か所謂良性ではなく，中には潜 在的に悪性つるのがある事を物語つている。

3 . 骨肉腫 6 例中 5 例飞枟移が発生し，中 4 例は肺 転移であり， . 之等はすべて切断后 1 〜 4 ケという早 期に而子断層撮影により始めて発見され，3 例は切 断后 3〜16 ケ月で死の転帰を取つた。「レ」線上では
殆んど全例が硬化像を示し, Alk-P-tase 值す之に比 例した增加と，切断による著减を示したが，転移発生 そ其の増加との間には，時期的なずれがあり，Alk-Ptase と骨肉腫の予后に関する Colley の説は再検討を 要する。又血管造影による肉腫の豊富な血管分布は， 切断前の試験切除の危険性を暗示している。

4. 脊惟㢎転移は「カリエス」と誤診され易いので 注意を要し, Alk-P-tase は一般に正常か低値の場 合 が多い事を再確認した。

（擱筆するに臨及, 終始御指導を頂いた西尾, 阿武両 教授並びに種々御協力を頂いた現九大整形外科教窒新 宮助手に深謝する)。

\title{
Hand-Schïller-Christian 氏病の一例
}

$\begin{array}{ccccc}\text { 久留米大学医学部整形外科教室 } & \text { 日 } & \text { 高 } & \text { 達 } & \text { 郎 } \\ & \text { 鹿 } & \text { 毛俄成圭教授 } & & \text { 進 }\end{array}$

A Case of Hand-Schüller-Christian's Disease

by

\author{
T. Hidaka \& S. Kage \\ Department of Orthopedic Surgery \\ Kurume University (Director: Prof. S. Miyagi)
}

地四状頭蓋を呈する疾患には骨髄腫, 癌の骨枟移, Hand-Schüller-Christian 氏病等種々見られるが，そ の中でる定型的な地図状頭蓋を呈するるのに HandSchüller-Christian 氏病がある。本症は 1893 年 Hand が初めて記載し 1915 年 Schüller により頭蓋骨に変化 を有する疾患として報告されその後，1919 年 Christian によつて更に詳細な報告を見た。臨床的に本症の 三主徽として, 地図状頭蓋, 尿崩症, 眼球突出を挙げ ているが三主徵が共存することは比較的少い。

本症の報告例は Eosinophilic ¿Granuloma との移 行型として報告されているのを加えれば可成り多数が 含まれ外国では 200 例に垂とし本邦では下田氏等が総 括して発表した 30 例に加えるに合計 46 例にのぼつて いる。

最近, 地四状頭蓋を呈し所々に骨欠損を認め, 烸床 症状は定型的では無いが組織学的检索によつて本症と
確認した 1 例を経験したので報告する。<smiles>[124IH]</smiles>

患者：【 女 満 2 年 5 ケ月

主 訴: 歩行障碍とるい瘦

家族歴：両親は血族結婚でなく父は結婚前ヒロポン 中毒で患者の出生頃より精神に異常を来し現在佮治槣 していない。母は健在。兄弟姉妹なし。

既往歷：出産は正期産なれど鈤子分娩，母乳栄養。 生後 2 年頃 (本症の初発と時期を同じくす) 麻疹に曜 患し更にその後，外耳揤兼中耳炎の診断の下に加潦し， 今なお，治療中である。

現病歴 : 処女歩行 1 年 6 ケ月だつたが满 2 年を過ぎ る貪に歩行時安定性がなくフラフラしたり, 急に尻餅 をついたりするのに気付いた。更にるい瘦は増加して 来るので某小児科で受診した所，栄养失調と診断され 